\title{
55 簡易残留ホルマリン濃度測定器の医療現場での応用例
}

酒見信義（酒見医科器械舗）

殺菌消毒剂としてホルマリンはその強い殺菌力と取 扱い易さから医療現場で消毒用によく使われている. 一方, Pabst, R. は解剖学ならびに組織学に従事して いる研究者, 技術者, また学生がかなりの濃度のホル マリン蒸気に暴露されている可能性があり, その健康 に対する危険性を指摘する論文を発表している（A. nat. Rec. 219 : 109, 1987).この指摘はホルマリンを 取り扱ら人々全体に対しても言えることである。今回, 第66回の本学会で発表した簡易残留ホルマリン濃度測 定器を使って医療現場でのホルマリン濃度を測定した。 测定は, 大阪府下の病院のリネン消毒室10箇所を 8 月と 12 月に, 獣医系の某大学解剖実習室 1 箅所を 5 月 に行った. 病院で汎用されているホルマリン消毒法は おもに次の 3 つである. 1. 重クロム酸カリとホルマ リンを反応させる. 2 . 特許電化 $\mathrm{K}$ 式消毒器を使う. 3. Jet-fog によるホルマリンの噴霧. 测定を行った 病院の消毒室は屋上に設置されたプレハブの建屋で,
その中に寝具や毛布類を吊り下げて床に上記の $1 \sim 3$ のぞれかを置いて消毒を行っている．水に濡らしたぺ 一パーディスクを瓶に入れて入口の戸を少し開けて横 棒に瓶を吊り下げ，ホルマリン櫓蒸後の室内のホルマ リン濃度を経時的に測定した. 大学の実習室の場合は ホルマリン固定した犬の死体を水洗後 3 日連続で使用 しており実習終了後は流水につけている，各実習日の 実習開始時の犬の体表面のホルマリン濃度を測定し， その後は実習室内のホルマリン濃度を経時的に測定し た.

病院の測定結果は，夏は約30時間で，冬は約40時間 で寝具および白衣の密着残留ホルマりン濃度が厚生省 令34条の溶出許容量の $75 \mathrm{ppm}$ 以下であった。奏習室 の場合は，入口の屝が実習中は開放されており，天井 も高く，測定開始後 1 時間で $5 \mathrm{ppm}$ 以下になった.

本測定器は操作が簡単であるので今後ホルマリンを 使った作業場の環境改善に役立つことと思う。

\section{6 中空系膜を応用した簡易液体浄化容器の性能とその臨床応用}

大久保憲 (刈谷総合病院外科・手術部) 神谷保廣 (刈谷総合病院中央医療機器室) 清水一夫，松本 悟 $($ トーメ一産業・研究開発部)

[はじめにポリエチレン微多孔質中空糸膜 ( $\mathrm{E} \mathrm{H}$ F）フィルターを装着した簡易液体浄化容器は, 水中 のコロイド粒子や浮遊する微生物を除去できる. 今回, 保存液中の有効成分に括よぼす影響, 微生物の濾過効 率, 一般臨床に拈ける応用について述べる.

[容器] 容器の本体は直径 $41 \mathrm{~mm}$, 高さ $148 \mathrm{~mm}$ の円 筒型で, 内容液の詰め替え可能な酎压エアゾル式容器 である. 中空糸膜モジュールは $\mathrm{EHF}$ 膜96本をループ 状に束小, 膜面積は $80 \mathrm{~cm}^{2}$ となる. 容器の加压は内 蔵されたピストンボーでポンプアップしておこない, ノズルからの唺出液量は最大 $90 \mathrm{ml} /$ 分（初期流量） である。

[方法]消毒剤の中空糸膜への吸着テストは, 塩化 ベンザルコニウム, グルコン酸クロルヘキシジン, ポ ビドンョードを用いて，吸光度測定法により濃度測定
を打こなった。

微生物の濾過効率試験は Pseudomonas aeruginosa $10^{6}$ cells $/ \mathrm{ml}$ を指標菌として使用した.

〔結果】各消毒剂の吸着量は的 $10 \sim 20 \mathrm{ml}$ の滤過量 で飽和に達し，それ以後は原液濃度と同等の濾過腋が 得られた，指標菌を生食水中に浮遊させたものについ ては, 内容液中にみられた細菌は完全に濾過されてい た。

[考察]在宅医療，救急外来あるいは病棟において 創偒の洗浄, 吸入液, 加湿器の補充液などに対して容 易に清潔な濾過水が得られるため有用な装置である. さらに消毒剂中に耐性菌が混入していた場合にも, 消 毒剂による創傷の洗浄を安全に和こなう事ができる. したがって本ボトルは院内感染防止の面からす今後広 く応用できるものと思われる. 